\title{
Being in Others: Empathy From a Psychoanalytical Perspective
}

\author{
Sarah Richmond
}

\begin{abstract}
'No longer to think of oneself'.--let us reflect seriously upon this question: why do we leap after someone who has fallen into the water in front of us, even though we feel no kind of affection for him? Out of pity: at that moment we are thinking only of the other person-thus says thoughtlessness. Why do we feel pain and discomfort in common with someone spitting blood, though we may even be ill-disposed towards him? Out of pity: at that moment we are not thinking of ourself-thus says the same thoughtlessness. The truth is: in the feeling of pity-I mean in that which is usually and misleadingly called pity-we are, to be sure, not consciously thinking of oneself but are doing so very strongly unconsciously... An accident which happens to another offends us: it would make us aware of our impotence, and perhaps of our cowardice, if we did not go to assist him. Or it brings with it in itself a diminution of our honour in the eyes of others or in our own eyes. Or an accident and suffering incurred by another constitutes a signpost to some danger to us; and it can have a painful effect upon us simply as a token of human vulnerability and fragility in general.
\end{abstract}

(Nietzsche 1881: §133)

I...came to recognize the major importance for identification of certain projective mechanisms which are complementary to the introjective ones. The process which underlies the feeling of identification with other people, because one has attributed qualities or attitudes of one's own to them, was generally taken for granted even before the corresponding concept was incorporated in psychoanalytic theory. For instance, the projective mechanism underlying empathy is familiar in everyday life.

(Klein 1955: 142-3)

We are inclined to attribute to other people-in a sense, to put into them-some of our own emotions and thoughts... By attributing part of our feelings to the other person, we understand their feelings, needs and satisfactions; in other words, we are putting ourselves into the other person's shoes. There are people who go so far in this direction that they lose themselves entirely in others and become incapable of objective judgement.

(Klein 1959: 252-3)

Empathy is a topic that has figured in a great deal of recent philosophical discussion. This is due in large part to spillover from the debate within the philosophy of mind about the basis of our psychological understanding of others. The exercise in psychological modelling that, simulationists have suggested (in

European Journal of Philosophy 12:2 ISSN 0966-8373 pp. 244-264 (C) Blackwell Publishing Ltd. 2004. 9600 Garsington Road, Oxford OX4 2DQ, UK, and 350 Main Street, Malden, MA 02148, USA. 
opposition to the 'theory theorists'), serves as our means of gaining interpersonal psychological understanding, overlaps significantly with empathy, as it is ordinarily understood, and this has given rise to much discussion of the precise relationship between simulation and empathy. ${ }^{1}$ The simulationist position has impinged also on moral philosophy, insofar as some of its advocates have claimed that the same empathic capacity underlies (some) moral thinking and generates moral motivation. ${ }^{2}$ And work in aesthetics has drawn on the same model to explain our emotional responses to fiction. ${ }^{3}$

Of course this 'new wave' of philosophical interest in empathy, thrown up by the development of simulation theory, is just that: earlier thinkers had argued for the relevance of empathy in each of these areas without the benefit of the precise description of its functioning that some simulationists have claimed to provide. Advocates of simulation theory frequently point out that Collingwood's early twentieth century claims about the mode of understanding appropriate to history-an imaginative reconstruction, on the part of the historian, of the thoughts of earlier peoples-have much in common with their own. In moral philosophy, Schopenhauer's Mitleid (usually translated as 'compassion'), the capacity for which, he claimed, provides the basis of morality, is recognisably an empathic experience. There is overlap too between the conception of sympathy in Hume's and Smith's moral philosophy, and that of empathy in contemporary discussion. ${ }^{4}$ And it was in aesthetic theory that the term 'empathy' was first coined: the English word entered the language in the early years of the twentieth century as a translation of the term Einfuhlüng ('feeling into') that had recently been coined in German to characterise a type of aesthetic response.

Empathy, then, has been of longstanding interest to philosophers. But these various treatments of the theme display a conspicuous lack of unity. Those in the earlier wave were each formulated quite independently of the others; in the more recent discussion, heavily influenced by the simulationist research programme, there is a greater appearance of unity, insofar as part of the point of the discussion has been to show the explanatory weight that the hypothesised simulationist mechanism might bear. Yet, as I argue below, there is an air of contrivance about the way empathy is conceived within this framework.

My aim in this paper is to consider empathy from the perspective of psychoanalytical theory. In particular, I explore a suggestion casually advanced in the writings of Melanie Klein, and endorsed by some of her followers. The suggestion to be elaborated is that empathy has its basis in projective identification, an unconscious mechanism of defence. Although this suggestion may at first sight be startling, I argue that, when it is construed along the lines suggested by some of Klein's followers, it is intuitively plausible. It is valuable too because it articulates a normative dimension according to which exercises of empathy can be assessed. Again, I claim that this dimension corresponds to an important everyday insight. And further, I suggest that it provides a convincing endorsement and substantiation of Nietzsche's famous rejection of Schopenhauer's ethics. In pursuing these ideas I mean to further the case, advanced in the writings of several recent philosophers (Cavell, Deigh,

(c) Blackwell Publishing Ltd. 2004 
Scheffler, Lear, Wollheim), for thinking that psychoanalysis has something of value to offer moral philosophy.

Psychoanalytical theory provides a comprehensive account of the mind, developed over many decades and incorporating a vast corpus of clinical data, within which it is natural to hope that empathy might be accommodated. This paper only begins to explore this possibility, an adequate explanation of which would require far more space. My final section, widening the focus of the earlier ones, briefly examines some psychoanalytical claims about the development and structure of the personality, in relation to which a fuller account would aim to situate empathy.

It might reasonably be thought that the first step in this discussion ought to be to define empathy. And presumably, if one aim here is to evaluate some theoretical appropriations of empathy, the definition ought to be maximally theoretically neutral. That turns out to be hard because, as mentioned earlier, the word 'empathy' first entered the English language (via German) as a new term within aesthetic theory. ${ }^{6}$ A definition of empathy that provides a useful starting point ought not to commit us to more than the core of the concept, and also to correspond to modern everyday usage of the term. In these respects, I think the recent definition given in the New Penguin English Dictionary (2000)_- the capacity for understanding and sharing another's feelings or ideas'-serves well.

\section{Klein's Suggestion}

Klein suggested more than once that projective identification is the basis of empathy (two statements of the claim are quoted at the beginning of the paper). The claim is initially startling for a number of reasons. In the first place, because it grounds the capacity for empathy, which we typically regard as benign, in a psychological mechanism that, as Klein describes it, is not only primitive and defensive, but also irrational, and typically aggressive; a mechanism, moreover, that involves the agent in misrepresenting other people. This last detail is particularly obstructive of any rapprochement of empathy and projective identification, insofar as we regard the former as, at least much of the time, a reliable source of information-as a means of gaining knowledge ('from the inside', as it is often said) about other people's minds. How then could empathy be based in projective identification? The two operations in question seem to work in diametrically opposed directions.

At this point a summary of Klein's account of projective identification is in order. Klein's claim (first elaborated in her seminal 1946 paper), is that human beings make wide use of this mechanism of defence in infancy and, although its character evolves with development, adults remain prone to it in later life. Projective identification makes use of unconscious phantasy primarily to defend the infant against impulses-especially destructive ones-arising within him that provoke intense anxiety and cannot be tolerated. The infant's own

(C) Blackwell Publishing Ltd. 2004 
aggression, Klein writes, arouses 'the anxiety of being destroyed from within' (1946: 5). In response, the infant phantasises that these impulses, 'bad parts of the self' (which, Klein states, the infant often equates with excrements) are expelled from the self, and lodged inside another person; usually, at this early stage of development, the mother. In the resultant phantasy, the mother is now represented (falsely) as the source of the aggression. 'Much of the hatred against parts of the self is now directed towards the mother' (Klein 1946: 8).

This last sentence might suggest that the phenomenon involves a straightforward substitution, in which properties are 'relocated', by means of the projective phantasy, from the self to another person. In fact, projective identification is far less straightforward. ${ }^{7}$ Klein makes it clear that the aspect of identification is to be taken in a strong sense: that is, the infant feels that part of himself has literally entered the other person; he might, for example, feel that he can thereby control them from within (and this sense of 'occupation' accounts, Klein suggests, for feelings of claustrophobia that are associated with the phantasy). Projective identification is narcissistic, in that the boundaries between self and other are not understood: a sort of merger takes place, so that the mother is used, not as a dustbin for parts of the self, but as an extension of the self. It is not surprising then that, although projective identification is a normal part of infantile development, its persistence (or regression to it) underlies psychotic illness in adult life.

This characterisation of projective identification, as a psychotic defence mechanism that disrupts the differentiation of self and other cannot be reconciled with empathy (which requires a sense of the distinction between the self and the other). It is significant that the connection Klein draws between the two phenomena is not mentioned in the 1946 paper; it appears, rather, in the later papers of 1955 and 1959 quoted above. By then the idea of 'projective identification' had been in circulation for several years, and had begun to be taken up, with differing emphases, by different analysts. Klein must, I think, have been thinking of the 'projective mechanism' she alludes to in a weaker sense. It is probably relevant, too, that the 1959 article was written for a non-specialist readership, which may have encouraged Klein to give herself more leeway in the use of her terms.

Some of Klein's followers, though, in endorsing her remarks, have failed to take due account of the difficulty in making sense of them. R.D. Hinshelwood, for example, tries to demonstrate Klein's claim, by exploiting the very metaphor-of 'putting oneself in another's shoes' - that she used in 1959:

When one talks of 'putting oneself in someone else's shoes' this is a description of empathy, but it is also a description of inserting a part of oneself, some capacity for self-perception, into someone else's positionin particular it is an experiencing part of oneself that is inserted in order to gain, in phantasy, their experience. This is a normal enough activity on the part of sensitive people, and can be loosely included within the group of phantasies of projective identification. (Hinshelwood 1991: 295)

(C) Blackwell Publishing Ltd. 2004 
This claim, once examined, surely fails: empathy does not involve inserting any 'part of oneself' into another person. Characterising that 'part' as a capacity for self-perception fudges the issue but in any case the idea conveyed by the 'shoes' metaphor is that one takes up the other person's point of view. This requires one to see the things the way they see them, which involves an imaginative reconstruction of their experience, rather than any phantasy of 'gaining' it, as if it were available to be plundered. (The metaphor says that it is the other's shoes that one enters-that is, their position-not their mind). One senses that Hinshelwood has to describe things in this odd way to build a bridge between empathy and the Kleinian understanding of projective identification: fidelity to the ideas, associated with the latter, of invasion or occupancy of the other person has caused the distortion here.

There is, nonetheless, a construction of projective identification, implicit in Klein's own thinking, that makes better sense of her suggestion about empathy. Another Kleinian disciple, Betty Joseph, exploits this, in her version of the suggestion:

In its earliest forms projective identification has no concern for the object... As the child moves toward the depressive position this necessarily alters: although projective identification is probably never entirely given up, it will no longer involve the complete splitting off and disowning of parts of the self, but will be less absolute, more temporary, and more able to be drawn back into the individual's personality-and thus be the basis of empathy. (Joseph 1988: 66)

In referring here to the 'depressive position', Joseph is drawing on Klein's important distinction between the two fundamental structures that, she thinks, characterise the mind. Of these, the 'paranoid-schizoid' position is the earliest, and projective identification, as Klein describes it in 1946, is a 'splitting' mechanism typical of that position in which (as the name implies) persecutory anxiety is dominant. In normal psychological development, the paranoidschizoid position is superseded by the depressive position, in which the person's representation, both of his own qualities, and those of others, is far more realistic. This more realistic representation reflects the person's increased capacity to tolerate unwelcome impulses that, earlier, he might have been driven to project into others: the use of 'splitting' mechanisms declines. And, insofar as objectrelations in the depressive position become less persecutory and paranoid, realistic 'concern' for other people becomes possible. ${ }^{8}$

Joseph's thought, then, is that against this 'depressive position' backcloth, where a relatively stable psychic constellation is in place, temporary uses of projective identification, that can be 'drawn back into the...personality' can provide the basis of empathy. How much further does this suggestion take us, in terms of a reconciliation of projective identification with empathy? At first sight, it might seem that it is no help at all: if, for example, projective identification is as distorting and confused as Klein suggests, how can it make any difference if it is only temporary?

(c) Blackwell Publishing Ltd. 2004 
I think, however, that Joseph's thought can be illuminating if we focus on the other part of her suggestion: less pathological instances of projective identification are not only 'more temporary', but also 'less absolute'. We can take this phrase as implying that, in these instances, projective identification does less violence to, is less at odds with, reality. In such cases, what may happen is that a person, correctly perceiving a certain state in someone else, 'empathises' with it in order to be able to 'live it out' in that person, at one remove. Where such a state would be difficult to acknowledge as their own, they can gain satisfaction from this vicarious involvement. ${ }^{9}$ In such cases, 'empathic' interest in another's state has a projective aspect, even though it does not misrepresent the state: it is motivated by a desire to focus on that sort of state as found in the other person, to avoid the responsibility, as it were, of direct ownership.

Anna Freud's brilliant, debunking analysis of 'a form of altruism' published in 1936 (a decade before Klein coined the term 'projective identification') illustrates this vicarious dimension to some types of interpersonal concern. Anna Freud cites a patient, employed as a governess, whose childhood desires to have children and beautiful clothes appeared, in adult life, to have evaporated:

What chiefly struck one about her as an adult was her unassuming character and the modesty of the demands which she made on life. When she came to be analyzed, she was unmarried and childless and her dress was rather shabby and inconspicuous. She showed little sign of envy or ambition and would compete with other people only if she were forced to do so by external circumstances. One's first impression was that... she had developed in exactly the opposite direction from what her childhood would have led one to expect and that her wishes had been repressed...(Freud 1936: 124)

As she acquired more knowledge of this patient, however, Anna Freud came to think that this first impression was mistaken. Rather than repressing her wishes, this patient pursued them vicariously (thus conforming to a familiar stereotype of the unfulfilled spinster, or maiden aunt):

When her life was examined in more detail, it was clear that her original wishes were affirmed in a manner which seemed scarcely possible if repression had taken place. The repudiation of her own sexuality did not prevent her from taking an affectionate interest in the love life of her women friends and colleagues. She was an enthusiastic matchmaker and many love affairs were confided to her. Although she took no trouble about her own dress, she displayed a lively interest in her friends' clothes. Childless herself, she was devoted to other people's children... She might be said to display an unusual degree of concern about her friends' having pretty clothes, being admired and having children Similarly, in spite of her own retiring behaviour, she was ambitious for the men whom she loved and followed their careers with the utmost interest. It looked as if her own life had been emptied of interests and

C) Blackwell Publishing Ltd. 2004 
wishes; up to the time of her analysis it was almost entirely uneventful. Instead of exerting herself to achieve any aims of her own, she expended all her energy in sympathizing with the experiences of people she cared for. She lived in the lives of other people, instead of having any experience of her own. (Freud 1936: 124-5)

Anna Freud's intention in this paper was to unmask the 'egoistic' gratification present in an apparently 'altruistic' attitude of 'sympathetic' involvement. Nonetheless, it would be a mistake to assume that in the case she describes the woman's extreme involvement in other people's lives necessarily detracted from the accuracy of her perception of their experiences. The people in whom she took such interest may not have felt misunderstood (although it seems plausible to suppose that they might have found her concern excessive or intrusive). Indeed, the 'hunger' of someone who denies herself certain experiences might enhance her perceptiveness of them in others: the gratification promised by empathic experience may foster an alertness to opportunities to undergo it.

This said, however, there is an important respect in which someone's 'projective' motivation must limit their capacity for empathy. The range of experiences she takes empathic interest in will be narrow, restricted to the types of experience she is disposed to project. And, once empathic interest has been engaged, it seems possible that the desire for vicarious satisfaction might hinder any further curiosity, leading the subject to over-assimilate another's wishes (say) to her own, and to overlook the respects in which they differ.

This way of substantiating Klein's suggestion about the relationship between projective identification and empathy overcomes the problem posed by the apparent opposition between the former, as Klein describes it in 1946, and the latter. In place of outright opposition, the suggestion (as Joseph seems to understand it), is that exercises of empathy may be tinged, to a varying extent, by a projective motivation that is 'less absolute', and therefore less distorting, than the psychotic defence mechanism of early infancy. This psychoanalytical understanding of empathy supplements our everyday understanding of it-as an exercise in 'sharing and understanding' another's state(s) of mind-by situating each such exercise in relation to the unconscious significance of the exercise for the subject. This unconscious significance is itself determined by the subject's own attitude towards the existence in herself of the types of state that she empathises with when they occur in somebody else. A spectrum stretches between the two 'positions', paranoid-schizoid and depressive, differentiated by Klein, and the normative dimension associated with this distinction is reflected in its impact on empathy. Thus, those instances of empathy at the more paranoidschizoid end of the spectrum will be the most 'blind', most opportunistic, and most inflexible in their understanding of the other person, while those at the depressive end will be the 'best' cases, open to a wider range of experience in the other person, and more open to discovery.

If this psychoanalytic insight about empathy is correct, we might expect it to be acknowledged-along with many other psychoanalytical ideas-in lay

(c) Blackwell Publishing Ltd. 2004 
thinking about empathy. Klein believes that it is: in the 1955 paper, she states that 'the projective mechanism underlying empathy is familiar in everyday life' and in the later one, as we have seen, she claims that the everyday talk of 'putting oneself in another's shoes' captures the same connection. She follows this last point with an observation about the danger of the projective aspect of empathy: 'There are people who go so far in this direction that they lose themselves entirely in others and become incapable of objective judgement'. Here, again, she is suggesting that an everyday insight-about the danger of over-absorption in others-recognises the phenomenon theorised in her writings.

\section{Further Developments in Psychoanalysis: Clinical Empathy}

In the 1950s-the decade in which Klein threw out her remarks about the connection between projective identification and empathy-these ideas were also informing the momentous debate, within the psychoanalytical movement, about the significance of the analyst's emotional response to the patient, or 'countertransference'. In a seminal paper of 1950, Paula Heimann (who started out as a disciple of Klein's), argued that the analyst's countertransference, handled properly, was a valuable clinical resource, 'an instrument of research into the patient's unconscious' (Heimann 1950: 81). In this Heimann departed from the 'intellectualist' orthodoxy of her time, inherited from Freud, according to which feelings stirred up in the analyst by the patient were at best irrelevant, and often obstructive, to the analysis and a likely indication that the analyst himself required further analysis. Klein, however, stuck to the traditional view and a rift with Heimann occurred. This development in the understanding of the countertransference, and related developments in the theory of projective identification, occurred without Klein's assent. Kleinian practitioners today have followed the splinter group on this issue. Nevertheless, the initially heterodox line of thought they developed gives an account of the role of projective identification in empathy that amplifies and lends further support to Klein's suggestion.

This period in the history of psychoanalytical theory is very complicated, and the ideas of empathy and projective identification figure within it in a number of different ways. ${ }^{10}$ Roger Money-Kyrle's 1956 contribution to the countertransference debate is of particular interest here: he argues, against the 'intellectualist' tradition, that the analyst's understanding of the patient is achieved in large part through empathy and that empathy itself deploys projective identification.

Money-Kyrle suggests that psychoanalytical work taps the analyst's parental impulses: symbolically, the patient stands to the analyst as a child to a parent. (Here Money-Kyrle, registering his dissent from classical Freudian thinking, maintains that the analyst's scientific curiosity is, on its own, 'a little too impersonal' to consitute his motivation (1956: 23)). And, if the patient stands for a child, a child stands, in turn, for 'an early aspect of the [parent's] self' (p. 23): thus, in understanding the patient, the analyst exploits his understanding of his

(C) Blackwell Publishing Ltd. 2004 
own early self (which, Money-Kyrle implies, will, in consequence of the analysis he has himself undergone, be excellent). Empathy involves identifications, of both projective and introjective types. The projective phase, which concerns us here, is that in which the patient is the representative of a former immature or ill part of [the analyst], including his damaged objects, which he can now understand and therefore treat by interpretation, in the external world' (pp. 23-4).

Money-Kyrle's account of the psychoanalyst's empathy with his patient illustrates a 'lucid', psychically sophisticated, use of projective identification which, because it involves projection of part(s) of the self accepted by the analyst does not carry the risk of distortion which accompanies the blinder (dissociative, or vicarious) uses of the mechanism we have considered. The projective identification employed in this type of empathy, then, is as far towards the 'depressive position' end of the spectrum identified earlier as possible, and improves on that exemplified in the case of the governess described by Anna Freud. Where a high level of psychological integration has been achieved, so that there is no need for the person either to deny, or to distance himself from, aspects of his self, projective identification can be used to record a commonality between individuals, and to provide a template by means of which another person may be understood. As Money-Kyrle notes, an exercise of this sort will still provide satisfaction by virtue of its unconscious significance: the 'reliving' of an encounter with an earlier or more immature self can consolidate, for the analyst, his understanding of those aspects of himself; or it may provide new opportunities to express impulses that his present self-understanding entails (Money-Kyrle mentions reparative impulses in this context). For Money-Kyrle, then, the beneficial and 'normal' use of countertransference occurs within empathic transactions that involve the analyst's projection of parts of his self that have been understood. 'Deviant' countertransference, constituting an impediment to the analysis, arises when 'the patient corresponds too closely with some aspect of [the analyst] which he has not yet learnt to understand' (p. 24).

According to this psychoanalytical model, the degree of psychic integration possessed by someone determines their ability to empathise effectively with other people. The 'self-possessed' person has, at his disposal, the widest range of experiences with which to identify in others, and the maximal capacity for accurate empathic engagement. Klein's suggestion, developed in this way, articulates a normative dimension to empathy that provides a criterion by which one can discriminate 'defective' instances and, at the same time, an account of their defectiveness. ${ }^{11}$

This psychoanalytical account also substantiates, and vindicates (at least in part) Nietzsche's rejection of the value of 'pity'. ${ }^{12}$

\section{Nietzsche vs Schopenhauer}

Nietzsche's thinking on this subject, as in so many other areas, converges with psychoanalytical theory: one of his chief criticisms of the 'philosophy of pity' is

(c) Blackwell Publishing Ltd. 2004 
that it misrepresents the pitier's experience as 'altruistic' and, according to this line of thought, admirable, when in fact it serves thoroughly egoistic ends. The objection here is not of course to egoism-Nietzsche is, repeatedly, profoundly suspicious of the value of altruism-but to the stupidity (thoughtlessness, as he puts it (Daybreak: \$133)), of those who conceive of pity as altruistic. In the passage from Daybreak quoted at the start of the paper Nietzsche claims that even though one may not, 'in the feeling of pity', consciously be thinking of oneself, one is 'doing so very strongly unconsciously'. A few lines later he suggests, as Anna Freud suggested about altruism, that one form of this unconscious self-involvement in others' plights is vicarious: 'an accident and suffering incurred by another constitutes a signpost to some danger to us'.

Scattered throughout Nietzsche's writings, in addition, is the claim that concern with others-of which pity is just an instance-is often a sign of a need to escape oneself. Nietzsche's comments here endorse Klein's perception of the danger, in empathy, of 'losing oneself in others'. In the passage of Thus Spake Zarathustra entitled 'Of Love of One's Neighbour', Nietzsche says, 'You flee to your neighbour away from yourselves and would like to make a virtue of it: but I see through your "selflessness"' (TSZ: 86). This 'fleeing' into otherdirected concern betokens a deficiency in self-love, according to Nietzsche: 'Your love of your neighbour is your bad love of yourselves' (p. 86). One's 'neighbour', in consequence, is needed to serve as a witness, testifying for a good image of oneself that could not be sustained without him: 'You invite in a witness when you want to speak well of yourselves; and when you have misled him into thinking well of you, you then think well of yourselves' (p. 87). In Beyond Good and Evil Nietzsche also invokes the possessive attitude of those who wish to help and, again, highlights the unacknowledged gain that motivates 'helpful and charitable people': 'one almost always finds that clumsiness which first adjusts and adapts him who is to be helped... with these imaginings they dispose of those in need as if they were possessions' (BGE: §194).

Nietzsche also suggests that pity typically betokens weakness in the face of suffering, and an incorrect evaluation of it. The weakness is manifested in the passive attitude that, Nietzsche suggests, both the pitier and the pitied one adopt towards suffering: it is indulged in, rather than overcome. Nietzsche suggests that with this type of pity, there is gratification in the sufferer's state. Perversely, pity, by choosing to dwell with suffering, makes a cult of it:

... of what account is the pity of those who suffer! Or, worse, of those who preach pity! There exists almost everywhere in Europe today a morbid sensitivity and susceptibility to pain, likewise a repellent intemperance in lamentation, a tenderization which, with the aid of religion and odds and ends of philosophy, would like to deck itself out as something higherthere exists a downright cult of suffering. The unmanliness of that which is in such fanatic circles baptized 'pity' is, I think, the first thing which leaps to the eye. (BGE: \$293)

(C) Blackwell Publishing Ltd. 2004 
In this passage, Nietzsche contrasts this attitude to suffering with the strength shown towards the weak by 'a man who is by nature master'. Here, as in other passages, Nietzsche's aversion to submission to feeling sounds an unexpectedly Kantian note, and indeed, in Daybreak, Nietzsche explicitly opposes Kant to Schopenhauer's 'philosophy of pity':

Kant still stands outside this movement: he expressly teaches that we must be insensible towards the suffering of others if our beneficence is to possess moral value-which Schopenhauer, in a wrath easy to comprehend, calls Kantian insipidity. (Daybreak: $\$ 132)^{13}$

The incorrect evaluation of suffering shown in the philosophical 'movement' that Nietzsche deplores appears in its assumption that suffering ought necessarily to be abolished. Nietzsche, instead, draws a distinction between a superior type of pity, associated with the artist and creator, which regards suffering as a discipline and the (presumably Christian) pity that understands man as a creature, 'pampers' and 'weakens' him (BGE: 225). The superior type of pity is invoked also in Thus Spake Zarathustra, where Nietzsche derides the (ordinarily) 'compassionate': 'Alas, where in the world have there been greater follies than with the compassionate? And what in the world has caused more suffering than the follies of the compassionate?' (TSZ: 114). Instead of the 'shameless' attitude of compassionate people, Nietzsche urges greater discretion in one's handling of distress: 'if you have a suffering friend, be a resting-place for his suffering, but a resting-place like a hard bed, a camp-bed: thus you will serve him best' (TSZ: 113-4). ${ }^{14}$

Of course, not every aspect of Nietzsche's attitude to pity has a counterpart in psychoanalytical thinking. In particular, Nietzsche's idea that pain, pleasure, and even 'wellbeing' are incorrect measures of the value of experience, and his alternative ideal of self-creation are not held in common. Nonetheless Nietzsche's negative assessment of the experience of Mitleid, and the account he gives of the gain that such an experience affords the pitier, displays a thoroughgoing anticipation of the psychoanalytical notion of projective identification. We do not know which German term, if any, Klein-a native German speaker-may have had at the back of her mind when she wrote, in English, of the projective basis of empathy but her analysis finds striking confirmation in Nietzsche's attack on Mitleid.

This brings us to the important issue of terminology. It may look as if the comparison of Nietzsche with Klein is forced, and his attack on pity carries no implications for empathy. Certainly, the two English terms do not coincide in meaning and have different connotations (for example, pity is frequently regarded, in ordinary thinking, as an unwelcome attitude, while empathy on the whole is not). However, if one bears in mind the fact that Nietzsche's criticisms are often directed against Schopenhauer; considers the German terms that these philosophers used; examines closely the content of some of their claims; and, finally, takes into account some relevant lexicographical history, the convergence that I am pointing to here is supported.

(c) Blackwell Publishing Ltd. 2004 
While Nietzsche's English translators, as we have seen, render the target of his criticisms as 'pity', Schopenhauer's translators use the term 'compassion' for the emotional experience to which Schopenhauer attaches such ethical importance, and which Nietzsche aims to discredit. ${ }^{15}$ In the German, however, both thinkers use the same word, Mitleid. (And this, of course, signals more clearly to readers of the original German texts than the English translations can, that Nietzsche is disagreeing with Schopenhauer). If one were to translate Mitleid as 'literally' as possible, in such a way as to make its structure transparent, one might say 'suffering with' (the structure of the English word 'compassion', then, makes it a better choice in this respect than 'pity'). Presumably, the explanation for the translators' different choice of terms is, as we have noted, that the English word 'pity', in some contexts, already has negative associations: Nietszche, we might say, construes Schopenhauer's Mitleid as 'pity' when he criticises it-or so his translators seem to have thought. On the other hand, their choice of 'pity' has the cost mentioned above: unlike 'compassion', it fails to mirror in its structure the idea of sharing or accompanying another in their suffering ('co-suffering'), which Mitleid conveys. And some of Nietzsche's remarks make it clear that this specific feature of Mitleid is something he has in mind in criticising it:

Why double your 'ego'! - To view our own experiences with the eyes with which we are accustomed to view them when they are the experiences of others-this is very comforting and a medicine to be recommended. On the other hand, to view and imbibe the experiences of others as if they were ours-as is the demand of a philosophy of pity-this would destroy us...(Nietzsche, Daybreak: §137)

My claim is that, although it would be incorrect (for a number of interesting reasons, mentioned below) to translate Schopenhauer's term Mitleid as 'empathy', it is nonetheless conceived by him as an empathic experience, and that at least some of Nietzsche's rejection of it rests on his disagreement with Schopenhauer about the nature and value of empathic involvement. Thus Nietzsche's thinking does, indeed, anticipate Klein's conception of empathy. But why then doesn't Schopenhauer use (the German for) 'empathy'? Here some fascinating lexicographical history comes into play: a dedicated term for empathy was coined only in the early twentieth century, when it was introduced first into German (as Einfühlung) and then, translated, into English ('empathy', a new coinage in English, entering the language in order to translate the German term). ${ }^{16}$ Einfühlung, then, was not historically available for use either by Schopenhauer or Nietzsche, and it would be historically misleading to translate Mitleid as 'empathy'. Nonetheless, the features that Schopenhauer highlights in his description of Mitleid are, unmistakably, empathic. Schopenhauer emphasises, repeatedly, that the experience of Mitleid is one in which a person adopts the perspective of the (suffering) other. ${ }^{17}$ This leads Schopenhauer to claim, at times, that the person also takes on, in feeling, the suffering itself-'in the case of [the other's] woe as such, I suffer directly with him, I feel his woe just as I ordinarily do

(C) Blackwell Publishing Ltd. 2004 
only my own...' (Schopenhauer 1839: §16, 144). It is this sort of talk that invites Nietzsche's charge, quoted earlier, against 'doubling one's ego'. Schopenhauer's emphasis on the likeness of feeling here leads him too close to a suggestion frequently associated with empathic experience, from which he wishes to dissociate himeself: namely, that Mitleid involves a confusion of self with the other. ${ }^{18}$ Schopenhauer has to reject this suggestion if he is to preserve the separation he desires, which we have seen Nietzsche ridicule, between Mitleid and egoism. So he insists, against a writer called Cassina, that the compassionate imagination is not 'deceived': 'His view is that compassion arises from an instantaneous deception of the imagination, since we put ourselves in the position of the sufferer, and have the idea that we are suffering his pains in our person. This is by no means the case; on the contrary, at every moment we remain...conscious that he is the sufferer, not we; and it is precisely in his person, not in ours, that we feel the suffering... We suffer with him and hence in him; we feel his pain as his, and do not imagine that it is ours. In fact the happier our state, and hence the more our consciousness of it is contrasted with the other man's fate, the more susceptible we are to compassion' (Schopenhauer 1839: §16, 147).

For Schopenhauer, as this quotation shows, Mitleid is a source of lucid emotional insight about the other, and represents a valuable cognitive and ethical achievement. Nietzsche, on the other hand, believes that this sort of involvement is, typically, an expression of weakness, and imbalance within the self. The psychoanalytical suggestion about empathy that we have been considering allows the possibility that both may be partially correct. We can say that Schopenhauer's conception, exaggerating the 'altruism' of the phenomenon, is of 'depressive position' empathy while Nietzsche, more pessimistically, focuses on the blindest, most projective instances of empathy, closer to the 'paranoidschizoid' end of the spectrum. ${ }^{19}$

\section{Recent Discussion of Empathy Within the Philosophy of Mind: Advantages of the Psychoanalytical Perspective}

We have seen how, construed along the right lines, Klein's suggestion accredits and substantiates our sense that instances of empathy can be more or less benign, more or less valuable from an ethical point of view. It accommodates the phenomenon of unhealthy interpersonal empathic involvement, in which a person's interest in others' feelings is damagingly limited by distortions in their self-knowledge. Klein's 'depressive position', with its acknowledgement of the separateness of persons, provides the basis for the 'right' sort of empathic engagement, from an ethical point of view.

The same phenomenon accounts also for a source of epistemological inadequacy in empathy: the 'escapist' aspirations of blindly projective exercises of empathy severely limit a person's openness to discovery. Someone whose empathy is motivated by a desire to find and relish some particular state(s) in another person will either lose interest or fail to notice if that person does not

(C) Blackwell Publishing Ltd. 2004 
quite fit the bill. And further, insofar as a person pursuing these gratifying experiences of empathy will be concerned to locate the mental states in question in others, he will not be able to draw on any self-understanding to provide an information resource. In other words, he will lack the 'template' of personal experience that Money-Kyrle's description of the most lucid type of empathy invokes. $^{20}$

These features of the psychoanalytical account of empathy provide a motivational setting for it, and articulate an important dimension (which, I have argued, corresponds to ordinary intuition) for its evaluation. In comparison, I think, the conception of empathy that has dominated recent discussion in the philosophy of mind appears impoverished and distorted by the framework and agenda it subserves. A brief overview of this conception will be sufficient to indicate these shortcomings. ${ }^{21}$

As mentioned earlier, the framework for most philosophical discussion of empathy (at least within the analytical tradition) within the last fifteen years or so, has been the debate between 'simulation theory' and 'theory theory'. ${ }^{22}$ The debate is over the correct explanation of our ability to attribute mental states to other people: do we do this, as simulationists contend, by using our own minds to model ('simulate') the mental processes of others or rather-as the theory theorists holdby applying a theory about psychological processes to them? It is not surprising, given the prima facie similarities between the ideas of simulation and empathy (the first-personal perspective, the reproduction of the mental states of another) that empathy has been fought over by the participants in this debate. Noting these similarities, simulation theorists have argued, using varying strategies, that the phenomenon of empathy (whose existence is readily conceded) provides support for the more controversial model of interpersonal psychological understanding they propose (Goldman 1993a, 1993b; Gordon 1995; Ravenscroft 1998).

One simulationist line of thought invokes economy of explanation here. Ravenscroft, for example, uses the computational metaphor that has been popular in these discussions to express such a claim. The metaphor invites us to understand exercises of simulation as an 'off-line' operation of our mental economy: in order to simulate other minds, we run our own mind, 'typically detached from its usual behavioural outputs' (Ravenscroft 1998: 179). (If I were not able to 'detach' this part of the mechanism, I would be unable to conclude from a simulation of someone else that they would behave in a certain way without behaving in that way myself). Ravenscroft argues that the detachment can be implemented to various degrees, and situates empathy in terms of this idea: 'Empathetic experiences occur when, following the introduction of pretend input, our mental economy is largely detached from behavioural output but nevertheless engages the mechanism involved in affective responses' (p. 179). This account of empathy as a variant of simulation is explanatorily economic, whereas rival accounts, Ravenscroft claims, involve an implausible 'duplication of causal pathways' within the mind (pp. 174-5).

Alvin Goldman, in similar vein, surveys various applications of the idea of simulation, and suggests that our ordinary concept of empathy corresponds to a

(c) Blackwell Publishing Ltd. 2004 
narrower sense of simulation, that is 'specifically concerned with affective or emotional states' (1993a: 197). This raises the question of why and how states that are generated by simulation feel, as empathic states feel, genuinely affective. Goldman's reply is that the 'pretend' states on which simulation operates are 'similar to, or homologous to' the target states that they mimic: they share some of the same properties. Goldman admits that this 'similarity' needs unpacking but suggests that this gives 'insufficient reason... to cede this territory to the skeptic' (p. 198). Simulation theory is apparently strengthened by its ability to account for empathy.

These accounts, by forcing empathy into the mould of simulation, do little to illuminate it. In particular, although the aspect of empathy that is definitionally central-'shared feeling'-is acknowledged, it is not explained: nothing helpful is said about why it occurs, or what function it might serve.

The characterisations of empathy offered by the participants in the simulation vs theory debate are also unduly polarised by the polemical purposes they serve. Goldman, for example, argues that the type of empathy based on 'role-taking' employs (and is, therefore, evidence for) a simulation mechanism: one takes up $X^{\prime}$ 's role, as one simulates, by imagining one is in $X^{\prime}$ 's situation (1993b: 95). But, as Goldman's opponents point out (Nichols, Stich et al 1996: 65-7), we do not have to understand 'role-taking' in these terms, as a purely imaginative exercise. It can also be explained in 'informational' terms: perhaps one employs one's own experience and memory, rather than one's imagination, to arrive at a conception of what $X^{\prime}$ 's situation is like. It seems likely in fact that many efforts to empathically enter into someone else's situation are informed by both imagination and memory, as when one deliberately recalls an experience of one's own in order to better imagine how it must be for someone else. ${ }^{23}$

A further criticism levelled against simulationist accounts of empathy is that they drive an explanatory wedge between 'high-level' instances of empathy, that supposedly deploy the cognitive and conceptual apparatus used in simulation, and the more primitive phenomena (such as the emotional contagion and motor mimicry exhibited by newborn infants) that are often thought of as empathic in a broader sense (Ravenscroft 1998: 181; Goldman 1993b: 143). Such a wedge is not necessarily illegitimate (it may well be that distinct mechanisms underlie different types of empathic response); the difficulty, though, is that it seems that the governing reason for isolating 'role-taking' empathy from other types is that it lends itself to description in simulationist terms. In other words, although it seems as if empathic phenomena provide independent support for the simulationist picture, their classification is in fact dictated by that picture.

In general, these simulationist appropriations of empathy focus on its cognitive and epistemological dimension, and underplay its affective features (which, as we saw for example in Ravenscroft's account, are often treated as if they were gratuitous supplements, accompanying on occasion the core materials of simulation). This surely distorts the 'folk' understanding of empathy, in which the idea of accompanying another person in feeling figures more centrally than that of learning something about their state of mind. A further limitation

(c) Blackwell Publishing Ltd. 2004 
of this narrow focus is that nothing is said about the role empathy plays within the psychologies of the people involved or about non-epistemological aspects of its contribution to interpersonal relationships. (For example the widespread phenomenon of dispositional empathy, which is often an important element in relationships between people who know each other well, is not mentioned).

Although I am not able to provide more than a sketch, I wish to indicate, in the following section, the importance and centrality of empathic phenomena within the psychoanalytical understanding of the personality and its development. The scope of these has not emerged in the preceding discussion (more narrowly focused on Klein's claim about empathy and projective identification) but aspects of the wider picture behind her claim suggest further dimensions of empathy worthy of further exploration.

\section{'Intrapersonal' Empathy}

Extending a line of thought introduced in his later writings by Freud, Klein regards acts of identification, with (for the most part) objects that are 'internal', as essential both to the structure of the personality, and to its development. ${ }^{24}$ Internal objects are represented, in phantasy, as existing within the body: they are established by phantasies of incorporation, in which an object (for example, the maternal breast) is represented as being taken into the self (ingested, for example). These objects come to constitute the 'internal world' that Klein postulates: their constellation determines the structure of the personality. As we saw, Klein believes that projective identification can serve to rid the subject, in phantasy, of parts of his self; correspondingly, she claims, acts of introjective identification enable the infant to acquire psychological resources. ${ }^{25}$

For Klein, the most fundamental internal object is the maternal breast. While its initial introjection may have been for defensive purposes (to protect the infant, for example, against the fear of its loss), this 'good' internal object provides a crucial focal point for further development:

If the mother is taken into the child's inner world as a good and dependable object, an element of strength is added to the ego. For I assume that the ego develops largely round this good object, and the identification with the good characteristics of the mother becomes the basis for further helpful identifications. (Klein 1959: 251)

The internalised good object brings about a real, not just phantasised, increase in psychological strength, insofar as the maternal perspective and capacities are felt to be available for the infant to take up and deploy. In other words, through an internalised empathic relationship, the infant is able to take up a point of view of himself which strengthens him. (Klein emphasises in particular how important this is for overcoming the most primitive anxiety, fear of one's own destructive

(C) Blackwell Publishing Ltd. 2004 
and aggressive impulses. The ego, at birth, is weak and fragmented; strength and unity are acquired only through the establishment of helpful internal figures, whose basis rests in turn on the baby's transactions with its 'external' carers). Thus abiding, dispositional identifications develop and give structure to the personality: and, in addition to the maternal figure, other internal figures (most famously, perhaps, the 'superego') underpin other perspectives that can be taken up, and other psychological capacities. ${ }^{26}$

Pathology, as we have seen, arises when the internal world that develops, for whatever environmental or innate reasons, is insufficiently facilitating; for example, when internal objects are felt to be excessively persecutory, and aggression in consequence spirals. In normal development, the personality becomes sufficiently integrated to manage the full range of instinctual impulses. The task of psychoanalysis is to foster this process, by acquainting a person more fully and explicitly with the shape of his unconscious mind.

This psychoanalytical model accords an important place to empathy within the psychology of the person. Developmentally, intra-personal acts of empathy (mediated by, and invoking the perspective of, internal figures) are shown to be essential to the growth of the personality. And structurally, the mind's unconscious representation of itself in terms of object relations packages its experience in a form that can readily be deployed by empathy. Thus, as MoneyKyrle's discussion shows, one's own relationship with an infantile part of oneself, for example, makes available a template that can be used in empathic understanding of another person's infantile aspects. ${ }^{27}$ (The fact that MoneyKyrle, as an analysed and practising psychoanalyst, explicitly understands his activity in these terms makes no important difference. In people unschooled in psychoanalytical theory, the projective identification he describes simply occurs, without their having the resources to name it. The difference is just that in their case, the unconscious motivation and gain remain unconscious).

The psychoanalytical conception of the mind accords an important developmental role to empathy, suggests the materials with which it works, supplies an understanding of its motivation, and provides a basis for a normative dimension that belongs to it. It shows at the same time why empathy is relevant both to philosophers of mind and to moral psychology. ${ }^{28}$ For these reasons, Klein's intriguing suggestion about empathy, and the psychoanalytical perspective it deploys, deserve philosophical attention. ${ }^{29}$

Sarah Richmond

Department of Philosophy

University College London

Gower Street

London WC1E 6BT

UK

s.richmond@ucl.ac.uk

(C) Blackwell Publishing Ltd. 2004 


\section{NOTES}

${ }^{1}$ The titles of some papers written by simulationists-for example, Heal's (1998) 'Understanding Other Minds from the Inside', and Goldman's (1993a) 'Empathy, Mind and Morals' - make this overlap explicit.

2 See Goldman 1993a and Gordon 1995.

${ }^{3}$ For example, Kendall Walton (1997) acknowledges the proximity between his celebrated 'make-believe' theory of our response to fiction, and simulation theory. Gregory Currie $(1995,1997)$ also puts simulation theory to use within aesthetics.

${ }^{4}$ See Gordon 1995 for discussion. Terminological issues in this area are very complicated. I touch on these later. Goldie 1999 and Darwall 1998 both provide helpful discussion of the difference between 'empathy', 'sympathy' and other closely related concepts.

5 The history of the term 'empathy' is germane to some claims I make later in the paper.

${ }^{6}$ The entry for 'empathy' in the Sixth Edition (1976) of the Concise Oxford English Dictionary (checked because I happened to have it at home) still retains vestiges of the aesthetic concept in which the term originated and therefore, I think, sounds rather odd to the modern ear: 'Power of projecting one's personality into (and so fully comprehending) the object of contemplation'. Clearly the editors at some point felt the same way, as in the most recent edition of the Concise Oxford (2002), the odd phrase does not appear. Instead, a definition almost identical with the New Penguin one is provided: '[the ability to] understand and share the feelings of another'.

7 The more straighforward operation of relocation is also recognised in psychoanalytical theory, and regarded as a widespread phenomenon. It is sometimes suggested that the term 'projection' tout court should be reserved for it, while 'projective identification' is reserved for the more psychotic mechanism Klein describes in 1946.

${ }^{8}$ It is important to note that the 'depressive position' represents a great psychic achievement, and that in reality no person can maintain it constantly: under stress, regression to a more paranoid-schoizoid position occurs. Most people fluctuate between the two psychic poles.

9 Some of the examples of projective identification that Klein describes (in particular in her 1955 paper) have this structure. See Klein (1955: 167-71) for discussion of motives underlying the choice of objects for projective identification.

10 For reasons of space, and focus, I will not discuss the hugely influential account of projective identification developed by Bion from the 1950s onwards.

${ }^{11}$ It also illustrates the way in which the ability to empathise is (as social psychologists have found) a developmental achievement. See Hoffman 2000 for relevant research.

12 Remarks about pity are scattered throughout Nietzsche's writings, and it is criticised on several counts. See Sprigge 2000, where twelve objections to pity raised by Nietzsche are distinguished and discussed. Here I am just concerned with those criticisms that exhibit, as I suggest, his concurrence with and anticipation of psychoanalytical thinking.

13 Kaufmann (1974: 365) also draws attention to Nietzsche's conscription of Plato, Spinoza and La Rochefoucauld as allies 'united on one point: their low opinion of pity' (GM, Preface, \$5). And Nussbaum 1994 argues that Nietzsche's atttitude towards pity and mercy revives the values of the Stoics.

14 The idea of an other, 'better' type of pity is a minor but recurrent theme in Nietzsche's writings. See Staten (1990: 153-5) for discussion of another distinction beween forms of identification in Nietzche's early writings.

(C) Blackwell Publishing Ltd. 2004 
15 Although there is discussion of compassion in the Fourth Book of Schopenhauer's World as Will as Representation (1819), his account of compassion is most fully stated in his On The Basis of Morality (1839), on which I draw here.

16 Although he was not the first to use it, the German psychologist Theodor Lipps gave prominence to the term Einfühlung (literally, 'feeling-in') in work published in 1903. In its earliest German uses, the term describes an aesthetic experience, in which the spectator 'enters into' a work of art. Lipps extended the term, beyond this aesthetic context, when he claimed Einfühlung was involved in our understanding of other minds. As the term, structurally, means 'feeling-in', it is tempting to think that Klein's knowledge of the German word may have encouraged her in connecting it with projective identification. Freud uses Einfühlung a number of times in his works, in a way that suggests his conception of it is indebted to Lipps (whose work he knew). See Pigman 1995 for an excellent account of Freud's usage.

17 One difference between Schopenhauer's term Mitleid and 'empathy' that should be mentioned, however (although I do not think it raises any difficulty for my discussion) is that Mitleid, unlike empathy, is restricted to painful experiences (leid meaning 'suffering'). Mitfreude in German-'rejoicing with' - provides a positive counterpart to Mitleid. One might argue that, given Schopenhauer's ethical interest in the concept, the restriction makes sense: the role of Mitleid is to alert someone to the nature of another's suffering, which thereby motivates them to relieve it.

${ }^{18}$ Hoffman's major psychological study of the role of empathy in moral development notes a tendency for empathic experience to slide into 'egoistic drift', in which the imaginary ' $\mathrm{I}$ ' (of the victim) is eclipsed, as it were, by the actual 'I' (2000: 56).

19 Although, as we have seen, Nietzsche alludes at times to a 'superior' type of pity, of which, it appears, few people are capable. I do not wish to suggest that recognising this difference in the types of empathy that Schopenhauer and Nietzsche focus on explains all their disagreement on the subject.

${ }^{20}$ In a (forthcoming) companion paper to the present one I consider in more detail the distortions in a person's understanding of others' mental states that projective identification produces, and consider the implications on the simulation vs theory theory debate of taking these into account.

${ }^{21}$ To speak of 'the' conception in the singular is to simplify. There are differences of detail within the simulationist accounts on offer. Nonetheless I think they are sufficiently similar for the simplification not to matter.

${ }^{22}$ For example, Kennett 2002, which is not even concerned with the debate, nonetheless borrows its characterisation of empathy 'construed as this imaginative process of simulation'. Holton and Langton 1998, also not principally concerned with that debate, likewise invokes the simulationist model as 'roughly synonymous' with empathy.

${ }^{23}$ Adams (2001: 380) also invokes the possibility of an 'information-based' account of empathy against Ravenscroft.

24 See Bronstein 2001 for an overview of the Kleinian understanding of internal objects, and its origins in Freud's thought.

${ }^{25}$ This sketch simplifies, and omits many qualifications to, Klein's account but it captures the elements that are important for my purposes here.

26 The notion of dispositional identification is therefore central to the Kleinian view. Dispositional identifications occur with external figures too. As mentioned earlier, this notion remedies a lacuna in the simulationist model, which fails to account for those empathic experiences that seem to occur spontaneously, without any initiating act of

(C) Blackwell Publishing Ltd. 2004 
simulative imagination. An initiating act is not necessary in these cases, because the other person's point of view has become habitual.

${ }^{27}$ Money-Kyrle's model of empathy overcomes therefore the polarisation mentioned earlier between simulationist and 'informational' accounts: on this model, empathy is an imaginative exercise that makes use of information about the self.

${ }^{28}$ I have not pursued the third line of thought, implicit in my earlier remarks, that a psychoanalytical perspective on empathy might also illuminate its aesthetic applications. Richard Wollheim explores this idea in several of his writings: see for example Wollheim (1984: 213-5) for an account of the forms of projection said to underlie the perception of nature and the appreciation of art. Price 1992 helpfully surveys and evaluates the 'genetic projectivism' that can be extrapolated from psychoanalysis for value theory.

${ }_{29}$ This paper was mostly written during a period of research leave co-funded by the AHRB: I am grateful for their support. It has benefited from discussion with Gudrun von Tevenar (specifically about Nietzsche, Schopenhauer and German terminology) and Neil Vickers (in relation to psychoanalytical ideas and literature). Thanks to both of them, and also to the anonymous EJP referee who made some helpful suggestions, including the title.

\section{REFERENCES}

Note: All references to Nietzsche and Schopenhauer are based on the mentioned English translations.

Adams, F. (2001), 'Empathy, Neural Imaging and the Theory versus Simulation Debate', Mind \& Language, vol 16, no 4, pp. 368-392.

Bronstein, C. (2001), 'What are Internal Objects?', in C. Bronstein (ed.) Kleinian Theory: A Contemporary Perspective. London: Whurr.

Currie, G. (1995), 'Imagination and Simulation: Aesthetics Meets Cognitive Science', in M. Davies and T. Stone (eds.) Mental Simulation. Oxford: Blackwell.

- (1997), 'The Paradox of Caring: Fiction and the Philosophy of Mind', in M. Hjort and S. Laver (eds.) Emotion and the Arts. Oxford: OUP.

Davies, M. and Stone, T. (eds.) (1995), Mental Simulation. Oxford: Blackwell.

Darwall, S. (1998), 'Empathy, Sympathy, Care', Philosophical Studies, 89: 261-82.

Freud, A. (1936), The Ego and the Mechanisms of Defence (trans C. Baines (1966)). London: The Hogarth Press.

Goldie, P. (1999), 'How we Think of Others' Emotions', Mind E Language, vol 14, no 4: 394-423.

Goldman, A. (1993a), 'Empathy, Mind and Morals', reprinted in M. Davies and T. Stone (eds.) (1995): 185-208.

_ (1993b), Philosophical Applications of Cognitive Science. Boulder, CO: Westview Press.

Gordon, R. (1995), 'Sympathy, Simulation, and the Impartial Spectator', Ethics, 105: 727-42.

Heal, J. (1998), 'Understanding Other Minds from the Inside', in A. O'Hear (ed.), Current Issues in Philosophy of Mind. Cambridge: CUP.

Heimann, P. (1950), 'On Counter-Transference', International Journal of Psychoanalysis, 31: 81-4.

Hinshelwood, R. D. (1991), A Dictionary of Kleinian Thought, (2nd ed). London: Free Association Books.

Hoffman, M. (2000), Empathy and Moral Development. Cambridge: CUP.

(C) Blackwell Publishing Ltd. 2004 
Holton, R. and Langton, R. (1998), 'Empathy and Animal Ethics', in D. Jamieson (ed.), Singer and His Critics. Oxford: Blackwell.

Hopkins, J. and Savile, A. (eds.) (1992), Psychoanalysis, Mind and Art. Perspectives on Richard Wollheim. Oxford: Blackwell.

Joseph, B. (1988), 'Projective Identification: Clinical Aspects', in J. Sandler (ed.) Projection, Identification, Projective Identification. London: Karnac.

Kaufmann, W. (1974), Nietzsche. Philosopher, Psychologist, Antichrist, (4th ed). Princeton: Princeton University Press.

Kennett, J. (2002), 'Autism, Empathy and Moral Agency', Philosophical Quarterly, Vol 52, No 208: $340-57$.

Klein, M. (1946), 'Notes on Some Schizoid Mechanisms', reprinted in Klein (1988): 1-24.

— (1955), 'On Identification', reprinted in Klein (1988): 141-75.

— (1959), 'Our Adult World and Its Roots in Infancy', reprinted in Klein (1988): 247-63.

- (1988), 'Envy and Gratitude' and Other Works 1946-63. London: Virago.

Money-Kyrle, R. (1956), 'Normal Counter-Transference and Some of Its Deviations', reprinted in E. Bott Spillius (ed.) Melanie Klein Today, vol 2: Mainly Practice. London: Routledge.

Nichols, S., Stich, S., Leslie, A., and Klein, D., (1996), 'Varieties of Off-Line Simulation', in P. Carruthers and P. Smith (eds.) Theories of Theories of Mind. Cambridge: CUP.

Nietzsche, F. (1881), Daybreak (trans R. J. Hollingdale, (1982)). Cambridge: CUP.

_ (1885), Thus Spake Zarathustra (TSZ) (trans R. J. Hollingdale, (1961)). Harmondsworth: Penguin.

— (1886), Beyond Good and Evil (BGE) (trans R. J. Hollingdale, (1973)). Harmondsworth: Penguin.

(1887), On the Genealogy of Morality (GM) (trans C. Diethe (1994)). Cambridge: CUP.

Nussbaum, M. (1994), 'Pity and Mercy: Nietzsche's Stoicism', in R. Schacht (ed.), Nietzsche, Genealogy, Morality. California: University of California Press.

Pigman, G. (1995), 'Freud and the History of Empathy', International Journal of PsychoAnalysis, 76: 237-56.

Price, A. W. (1992), 'Three Types of Projectivism', in J. Hopkins and A. Savile (eds.) Psychoanalysis, Mind and Art. Perspectives on Richard Wollheim. Oxford: Blackwell.

Ravenscroft, I. (1998), 'What is it Like to be Someone Else? Simulation and Empathy', Ratio, XI, Issue 2: 170-85.

Schopenhauer, A. (1839), On the Basis of Morality (trans E. F. J. Payne (1995)). Providence, R.I.: Berghahn Books.

Sprigge, T. L. S. (2000), 'Is Pity the Basis of Ethics? Nietzsche versus Schopenhauer', in W. Sweet (ed.) The Bases of Ethics. Milwaukee: Marquette University Press.

Staten, H. (1990), Nietzsche's Voice. Ithaca: Cornell University Press.

Walton, K. (1997), 'Spelunking, Simulation, and Slime: On Being Moved by Fiction', in M. Hjort and S. Laver (eds.) Emotion and the Arts. Oxford: OUP.

Wollheim, R. (1984), The Thread of Life. Cambridge: CUP.

(C) Blackwell Publishing Ltd. 2004 